$\begin{array}{cc}\text { ACADEMIA ROMÂNĂ } & \text { Rev. Roum. Chim., } \\ \text { 2019, 64(9), 801-808 } & \text { Revue Roumaine de Chimie } \\ \text { http://web.icf.ro/rrch/ } & \text { DoI: 10.33224/rrch.2019.64.9.07 }\end{array}$

\title{
QUANTITATIVE DETERMINATION OF PARACETAMOL, CAFFEINE AND CODEINE PHOSPHATE IN PHARMACEUTICAL DOSAGE FORMS BY USING CAPILLARY ELECTROPHORESIS METHOD
}

\author{
Koray CAKIR, ${ }^{\mathrm{a}}$ Cem ERKMEN, ${ }^{\mathrm{b}}$ Bengi USLU ${ }^{\mathrm{b}}$ and Nilgun GUNDEN GOGER ${ }^{\mathrm{a},}$ \\ ${ }^{a}$ Gazi University, Faculty of Pharmacy, Department of Analytical Chemistry, 06330, Ankara, Turkey \\ ${ }^{\mathrm{b}}$ Ankara University, Faculty of Pharmacy, Department of Analytical Chemistry, 06560, Ankara, Turkey
}

Received February, 25, 2019

A new capillary electrophoresis method has been developed to analysis of paracetamol (PAR), caffeine (CAF) and codeine (COD) phosphate from pharmaceutical dosage forms. Good results were obtained by using a background electrolyte solution consist of $25 \mathrm{mM}(\mathrm{pH} 8.5)$ phosphate buffer solution containing $10 \%$ methanol. The separation was performed through an uncoated fused-silica capillaries $(50 \mu \mathrm{m}$ internal diameter, 56 $\mathrm{cm}$ total length, $47.5 \mathrm{~cm}$ effective length) at $25^{\circ} \mathrm{C}$ with the application of 10 seconds of hydrodynamic injection at 40 mbar pressure and a potential of $27 \mathrm{kV}$. Detection wavelength was chosen $210 \mathrm{~nm}$. Under optimum conditions, the migration times were found $4.427 \mathrm{~min}$ for PAR, $3.952 \mathrm{~min}$ for CAF, and $3.253 \mathrm{~min}$ for COD-phosphate. Linearity ranges were determined $99.72-1994.40 \mu \mathrm{g} \mathrm{mL}^{-1}$ for PAR, $5.75-115.04 \mu \mathrm{g}$ $\mathrm{mL}^{-1}$ for $\mathrm{CAF}$ and $1.84-36.80 \mu \mathrm{g} \mathrm{mL} \mathrm{m}^{-1}$ for COD-phosphate for the method. Limit of detections were found $0.724 \mu \mathrm{g} \mathrm{mL} L^{-1}$ for PAR, 0.533 $\mu \mathrm{g} \mathrm{mL}{ }^{-1}$ for CAF and $0.263 \mu \mathrm{g} \mathrm{mL}^{-1}$ for COD-phosphate in this study. Also, limit of quantitations were found $2.415 \mu \mathrm{g} \mathrm{mL}^{-1}$ for PAR, $1.776 \mu \mathrm{g} \mathrm{mL}^{-1}$ for CAF and $0.877 \mu \mathrm{g} \mathrm{mL} \mathrm{L}^{-1}$ for COD-phosphate. According to the obtained results, the method is sensitive, specific and repeatable to analysis of PAR, CAF and COD- phosphate.

\section{INTRODUCTION}

Paracetamol (PAR) is a readily available antipyretic and analgesic compound as shown in Figure 1. It also known as N-acetyl-p-aminophenol or acetaminophen. It is the most frequently recommended drug to treat mild-to-moderate pain or fever in patients, including neonates. It can be taken by different routes such as rectal, oral or intravenous. ${ }^{1}$

Codeine (COD) (methylmorphine) (Figure 1) is an alkaloid. It is extracted from poppy plants belonging the family of opiates. Also, it may be synthesized by methylation from morphine.

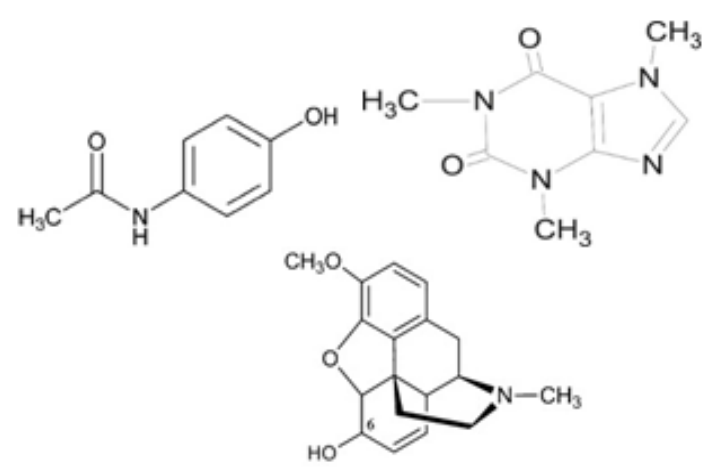

\footnotetext{
${ }^{*}$ Corresponding author: ngoger@gazi.edu.tr; Tel: +90 312 2023104; Fax: +90 3124333419
} 
stimulating properties. It is diuretic, enhances mental focus, decreases fatigue, and athletic performance and presents thermogenic effects. CAF has an excellent safety profile when consumed in moderate doses (around $0.2 \mathrm{~g} /$ day). However, in higher dosages (more than $2 \mathrm{~g}$ /day), it can cause arrhythmias, severe hypertension, seizures and even death. ${ }^{3}$

As an opioid, COD is a slightly stronger painkiller. Opioid painkillers work by mimicking the action of natural pain-reducing chemicals called endorphins that are produced in the brain and spinal cord. COD acts on the same opioid receptors as natural endorphins, and this blocks the transmission of pain signals sent by the nerves to the brain. This means that even though the cause of the pain may remain, less pain is actually felt. Several capsules, tablets, and soluble tablets contain COD, which in combination with the PAR is effective at relieving mild to moderate pain. Also, CAF is a weak stimulant that may enhance the painkilling effects of PAR. It may also counteract any drowsiness caused by the COD. ${ }^{4}$ For these reasons, there are pharmaceutical drugs containing PAR, COD and CAF in the market.

Capillary electrophoresis (CE) is an electrokinetic analytical technique for the separation of ionic species by their relative electrophoretic mobilities. ${ }^{22} \mathrm{CE}$ is one of the major separation tools because it can be applied to the separation of a wide range of compounds from small ions to biomolecules such as proteins and DNA. Therefore, the number of applications of CE in biological research is rapidly expanding; since the first report on CE in the 1980s, CE is now also used in medical and pharmaceutical sciences and environmental studies. ${ }^{35}$

In the literature, there are different methods for the analysis of mixtures containing binary and triple compounds which is selected in the study. There are high performance liquid chromatography methods (HPLC), ${ }^{7,20,23,26}$ magnetic solid-phase extraction (MSPE) method, ${ }^{8}$ liquid chromatography-tandem mass spectrometry (LC-MS/MS), ${ }^{25}$ electrochemical methods, ${ }^{12-14,18,21,28-32}$ spectropho- tometric methods ${ }^{10,16,17,33,34,36}$ and spectrofluorimetric methods ${ }^{6,9}$ for the analysis of mixtures containing binary or triple compounds which contains PAR, CAF and COD. Also, there are capillary electrophoresis method ${ }^{9}$ for analysis CAF and PAR and capillary zone electrophoresis method $^{37}$ for analysis CAF and COD. As can be seen in the literature studies, the method of capillary electrophoresis developed for the simultaneous determination of PAR, COD and $\mathrm{CAF}$ is not available. The most important feature of the CE method is the high separation power in short analysis time. The high resolution obtained by $\mathrm{CE}$ enables the analysis of compounds that are indistinguishable by spectroscopic techniques. This method is inable to use the minimum amount of solvent and sample according to HPLC or spectroscopic methods. So, CE method is more environmentally friendly. Also, the devices used in the $\mathrm{CE}$ method are more economical than the devices used in the LC-MS /MS method. Therefore, it is aimed to develop a method of capillary electrophoresis separation and simultaneous quantification of PAR, CAF and COD-phosphate in the form of tablets in this study.

\section{MATERIAL AND METHOD}

\section{Instrumentation}

All experiments were carried out on a HP3D CE (Agilent Technologies, Waldbronn, Germany) system, equipped with UV diode-array detector (DAD) operated at a wavelength of $210 \mathrm{~nm}$. Optimum wavelength for the target analyte was determined using 'Isoabsorbance' and '3-D' plots in the instrument's 'Data Analysis' software (Agilent Technologies). $\mathrm{pH}$ measurements were performed with an Orion $720 \mathrm{~A}+$ potentiometer (Termo Fischer Scientific, New Hampshire, USA) connected to a Schott Blueline 11-pH glass combination electrode (SI Analytics $\mathrm{GmbH}$, Mainz, Germany).
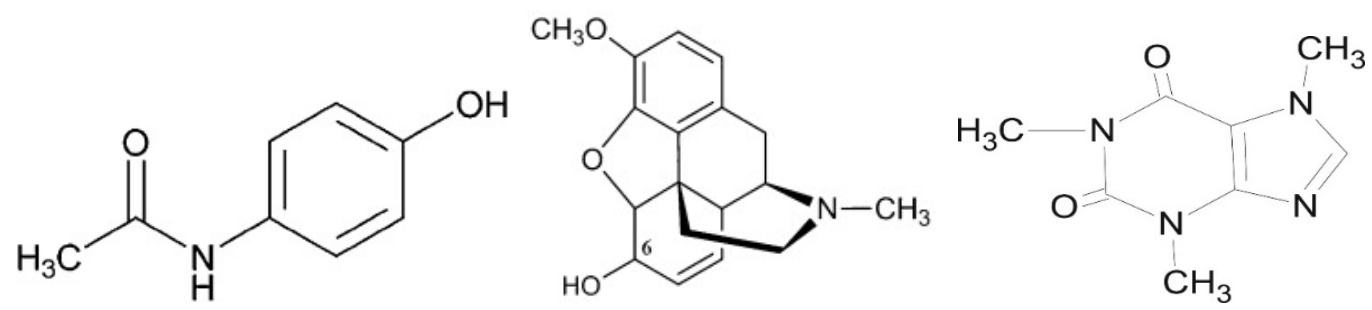

Fig. 1 - Chemical structure of PAR, COD and CAF. From left to right. 


\section{Materials}

A Millipore direct-Q 3UV ${ }^{\mathbb{B}}$ water purification system (Millipore, Bedford, MA, USA) was used to provide deionized water. PAR, CAF- citrate and COD-phosphate were purchased from Munir Sahin Ilac Sanayi ve Ticaret A.S. Methanol was HPLC grade and it was obtained from Sigma Aldrich (Steinheim, Germany). Disodium hydrogen phosphate dihydrate $\left(\mathrm{Na}_{2} \mathrm{HPO}_{4}\right)$ was analytical grade and it was obtained from Merck (Darmstadt, Germany). Electrophoresis was performed using uncoated fused-silica capillaries (Postnova Analytics, Landsberg, Germany) of $50 \mu \mathrm{m}$ i.d. and $56 \mathrm{~cm}$ length with effective length to the detector of $47.5 \mathrm{~cm}$. All solutions and samples were degassed using a sonicator (Sonorex Bondelin Electronic, Walldorf, Germany) and filtered through $0.20 \mu \mathrm{m}$ filters (Econofilters, Agilent Technologies, Darmstadt, Germany) before use.

\section{Method \\ of Optimization and Validation Studies}

In the literature search, it was seen that phosphate buffer was generally suitable for the analysis of compounds. ${ }^{38}$ The aqueous solutions of these compounds show weak basic properties. Therefore, $20 \mathrm{mM}$ and $25 \mathrm{mM} \mathrm{Na} \mathrm{HPO}_{4}$ buffer solutions were prepared to analysis. $25 \mathrm{mM}$ $\mathrm{Na}_{2} \mathrm{HPO}_{4}$ buffer containing $10 \%$ methanol at $\mathrm{pH}=$ 8.5 was used as working buffer solution (electrolyte solution). From the standards of the compunds, a solution containing $14.8 \mu \mathrm{g} / \mathrm{mL}$ COD-phosphate, $44.4 \mu \mathrm{g} / \mathrm{mL}$ CAF and $741 \mu \mathrm{g} / \mathrm{mL}$ PAR was prepared using working buffer. Analyses were performed at injection times of 5,10 , and 15 seconds and the injection pressure was kept constant at $40 \mathrm{mBar}$.

In order to determine the repeatable of the proposed method, a synthetic mixture containing standard substances similar in proportions to the tablet was prepared. $3.1 \mathrm{mg}$ COD-phosphate, $9.9 \mathrm{mg}$ of CAF-citrate that equivalent to $4.98 \mathrm{mg}$ CAF and $99.9 \mathrm{mg}$ PAR were weighed precisely and dissolved in $25 \mathrm{~mL}$ flask using working buffer. The final concentrations of analytes were $62 \mu \mathrm{g} / \mathrm{mL}, 99.6 \mu \mathrm{g} / \mathrm{mL}, 1998 \mu \mathrm{g} / \mathrm{mL}$ for CODphosphate, CAF and PAR respectively. The obtained solution was measured seven times under optimum conditions. For each compound, mean, standard deviation (SD) and relative standard deviation (RSD) values were calculated according to peak area, peak height and migration time.

\subsection{Calibration Studies}

To prepared stock solution, $4.6 \mathrm{mg}$ CODphosphate, $28.6 \mathrm{mg}$ CAF-citrate that equivalent to $14.38 \mathrm{mg}$ CAF and $249.3 \mathrm{mg}$ PAR were weighed precisely and transferred to a $50 \mathrm{~mL}$ flask, finally the volume was completed with working buffer solution. From this stock solution, $0.2,0.5,1.0,2.5$ and 4.0 $\mathrm{mL}$ were taken to $10.0 \mathrm{~mL}$ and were completed with working buffer. These solutions were measured three times in optimized conditions and the mean of the peak areas in the electropherograms were obtained and the calibration curves were drawn for each analyte separately.

\subsection{Determination of Paracetamol, Caffeine and Codeine Phosphate in Pharmaceutical Tablets}

A total of 10 Geralgine $\mathrm{K}^{\circledR}$ tablets were weighed and powdered. $53.6 \mathrm{mg}$ of tablet powder was weighed, equivalent to $39.7 \mathrm{mg}$ of PAR, 2.4 $\mathrm{mg}$ of CAF and $0.8 \mathrm{mg}$ of COD-phosphate and completed with working buffer solution to 50.0 $\mathrm{mL}$. The peak area values of the obtained solution were determined and in the same conditions, the amount of PAR, CAF and COD-phosphate in the tablets was calculated with the help of the calibration curves.

\subsection{Recovery Studies}

$240 \mu \mathrm{L}, 250 \mu \mathrm{L}$ and $260 \mu \mathrm{L}$ of stock standard solution which contains $5007 \mu \mathrm{g} / \mathrm{mL}$ PAR, 309 $\mu \mathrm{g} / \mathrm{mL}$ CAF and $104 \mu \mathrm{g} / \mathrm{mL}$ COD-phosphate were added to $9.0 \mathrm{~mL}$ of tablet solution which contains of $794 \mu \mathrm{g} / \mathrm{mL}$ PAR, $48 \mu \mathrm{g} / \mathrm{mL}$ CAF and $16 \mu \mathrm{g} / \mathrm{mL}$ COD-phosphate. The final volume was completed with $10.0 \mathrm{~mL}$ of working buffer. The obtained solutions were measured under optimized conditions and the \% recovery values were calculated from the calibration curves.

\section{RESULTS AND DISCUSSION}

\section{Results of Optimization Studies}

The aqueous solutions of COD-phosphate, CAF and PAR show weak basic properties. Therefore $\mathrm{Na}_{2} \mathrm{HPO}_{4}$ was chosen as the buffer solution. $\mathrm{Na}_{2} \mathrm{HPO}_{4}$ buffer was suitable for the separation of 
analytes as seen in Figure 2 and Figure 3. When $20 \mathrm{mM} \mathrm{Na} \mathrm{HPO}_{4}$ buffer was used the solubility of peaks was high because of slow electroosmotic flow (EOF). However, the COD-phosphate and CAF peaks expanded due to slow EOF. Also, PAR was removed after 8 minutes. When $20 \mathrm{mM}$ buffer solution was chosen, the current was $34 \mu \mathrm{A}$ and when $25 \mathrm{mM}$ buffer solution was used, the current was $42 \mu \mathrm{A}$. This explains the increase in both ionic strength and EOF when $25 \mathrm{mM}$ buffer solution was used, thus the migration times were change. When 25 $\mathrm{mM} \mathrm{Na} \mathrm{HPO}_{4}$ buffer was used, the EOF was faster. Therefore, the analysis time was shortened and the peak shapes improved. The peaks of the analytes were sufficient for separation under these conditions. The amounts of analytes in the studied tablet were quite different. Each tablet contains $500.0 \mathrm{mg}$ of PAR, $30.0 \mathrm{mg}$ of CAF and $10.0 \mathrm{mg}$ of CODphosphate. Considering that PAR, which has a very high amount, is less soluble in water, $10 \%$ methanol was added to the working buffer solution.

Based on the literature research, while the pressure was $40 \mathrm{mBar}$ and the voltage was $27 \mathrm{kV}$, injection times were set at 5, 10, and 15 seconds.
The electropherograms obtained in these conditions are shown in Figure 4, Figure 5 and Figure 6. The electropherogram that injection time is 15 seconds, shows that peaks are expanded, peak symmetries are not appropriate, and CAF and PAR peaks do not have a sufficient resolution for analysis. The electropherogram that injection time is 5 seconds shows that the shape of the peaks is sharp and symmetrical. However COD-phosphate that concentration is too low, cannot give a clear signal at lower concentrations at this injection time. The electropherogram that injection time is 10 seconds shows that the shape of the peaks is sharp and symmetrical. Considering that in this injection time, COD-phosphate can give a clear signal at low concentrations. Consequently it was determined that the injection time would be 10 seconds and the injection pressure would be 40 mbar. Also $56 \mathrm{~cm}$ long $(47.5 \mathrm{~cm}$ effective length) and $50 \mu \mathrm{m}$ inner diameter capillary were used throughout the study and a good resolution and short analysis time were obtained. Therefore, there was not use to experiment with capillaries that have different diameters and lengths.

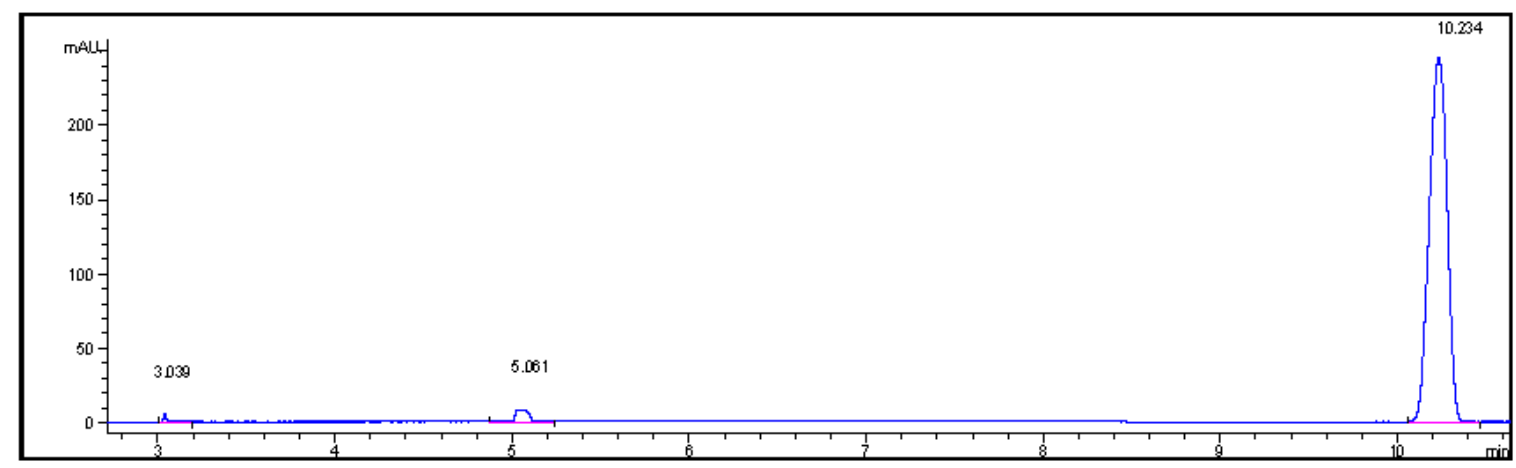

Fig. 2 - Electrophogram of the mixture of PAR, CAF and COD-phosphate; PAR $(570 \mu \mathrm{g} / \mathrm{mL}), \mathrm{CAF}(34.2 \mu \mathrm{g} / \mathrm{mL})$, COD- phosphate $(11.4 \mu \mathrm{g} / \mathrm{mL})$, Electrolyte Solution: $20 \mathrm{mM}$ phosphate buffer containing 10\% methanol. The order of peaks; COD-phosphate, CAF, PAR.

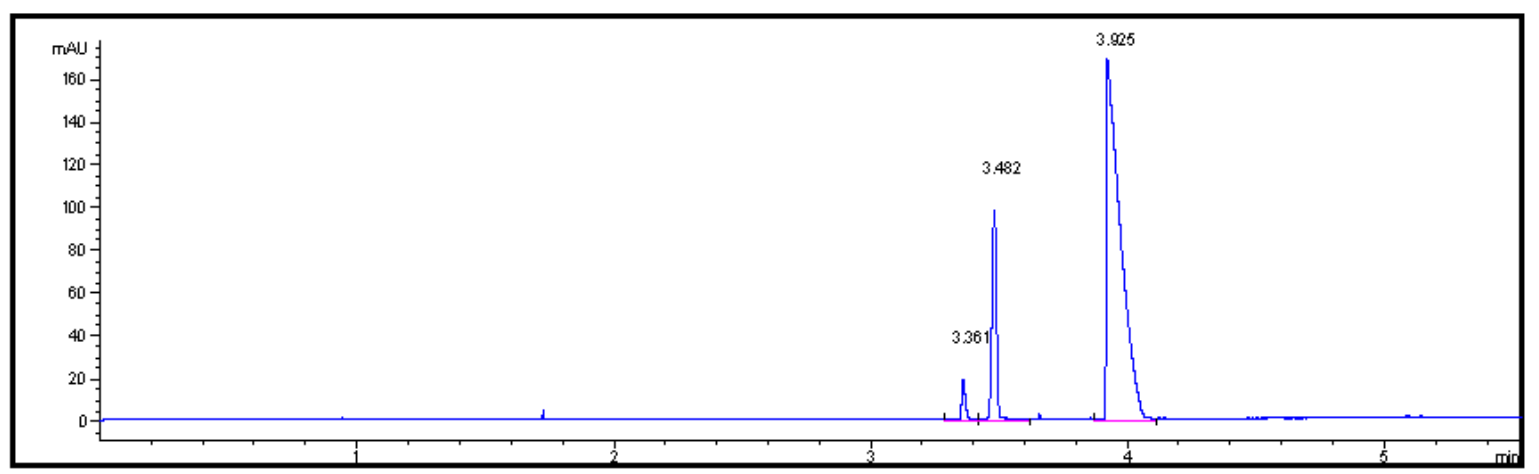

Fig. 3 - Electrophogram of the mixture of PAR, CAF and COD-phosphate; PAR (1050 $\mu \mathrm{g} / \mathrm{mL}), \mathrm{CAF}(63 \mu \mathrm{g} / \mathrm{mL}), \mathrm{COD}-$ phosphate $(21 \mu \mathrm{g} / \mathrm{mL})$, Electrolyte Solution: $25 \mathrm{mM}$ phosphate buffer containing $10 \%$ methanol. The order of peaks; COD-phosphate, CAF, PAR. 


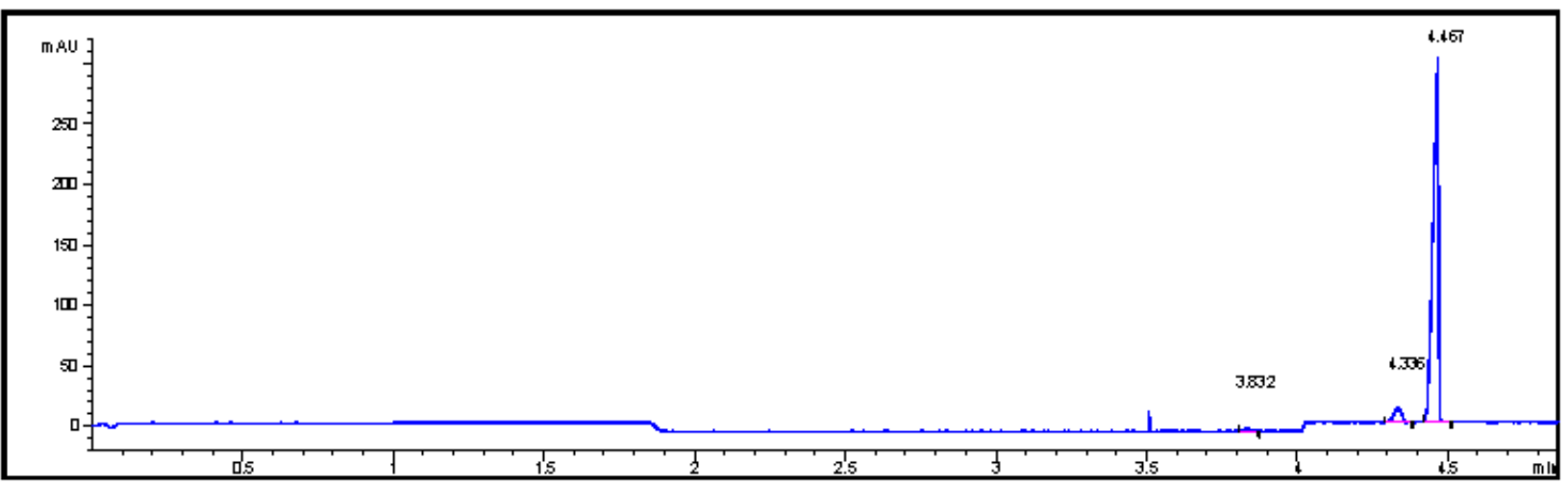

Fig. 4 - Electrophogram of the mixture of PAR, CAF and COD-phosphate; PAR (741 $\mu \mathrm{g} / \mathrm{mL})$, CAF $(44 \mu \mathrm{g} / \mathrm{mL})$, COD- phosphate $(14.8 \mu \mathrm{g} / \mathrm{mL})$, Electrolyte Solution: $25 \mathrm{mM}$ phosphate buffer containing $10 \%$ methanol, Injection time: 5 seconds. The order of peaks; COD-phosphate, CAF, PAR.

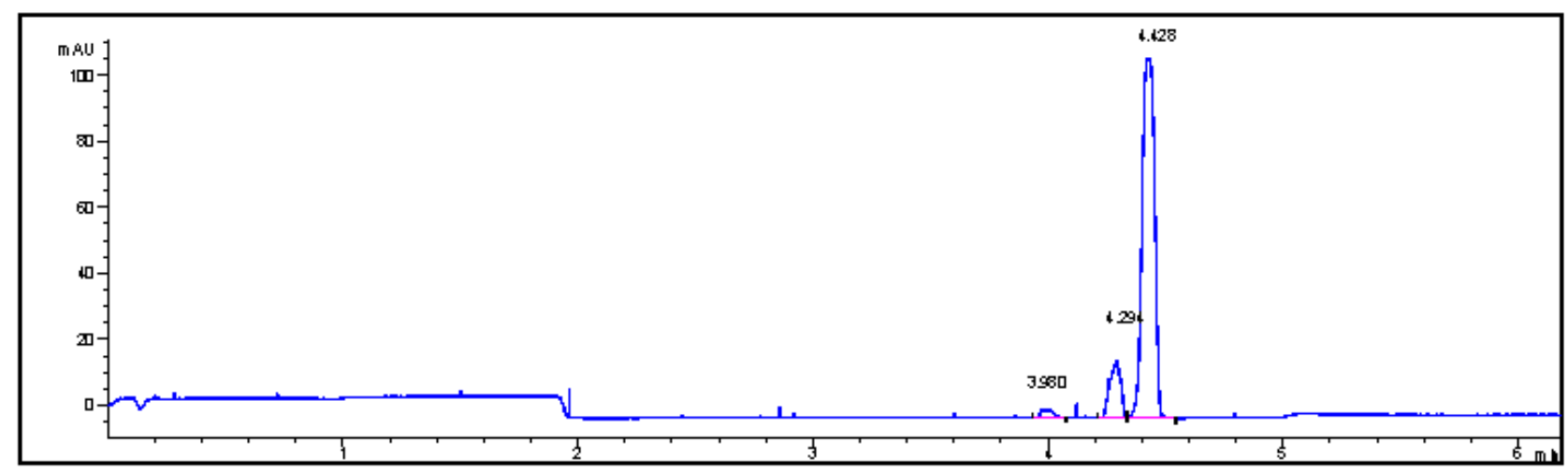

Fig. 5 - Electrophogram of the mixture of PAR, CAF and COD-phosphate; PAR $(741 \mu \mathrm{g} / \mathrm{mL}), \mathrm{CAF}(44 \mu \mathrm{g} / \mathrm{mL})$, COD- phosphate $(14.8 \mu \mathrm{g} / \mathrm{mL})$, Electrolyte Solution: $25 \mathrm{mM}$ phosphate buffer containing $10 \%$ methanol, Injection time: 10 seconds. The order of peaks; COD-phosphate, CAF, PAR.

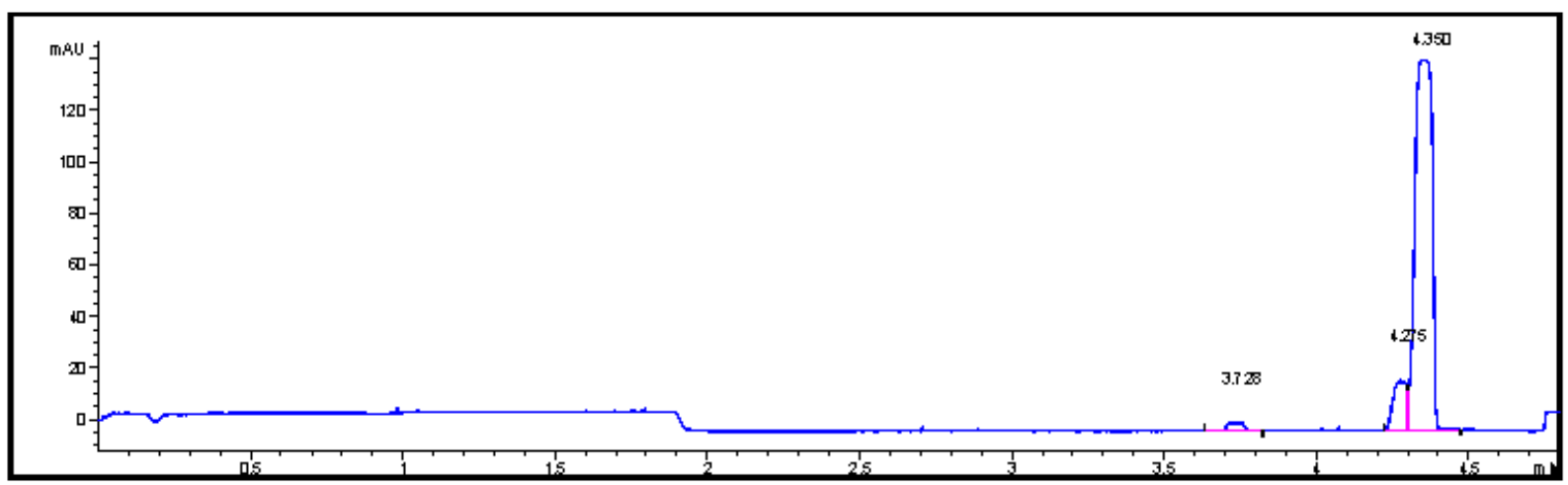

Fig. 6 - Electrophogram of the mixture of PAR, CAF and COD-phosphate; PAR $(741 \mu \mathrm{g} / \mathrm{mL}), \mathrm{CAF}(44 \mu \mathrm{g} / \mathrm{mL})$, COD- phosphate $(14.8 \mu \mathrm{g} / \mathrm{mL})$, Electrolyte Solution: $25 \mathrm{mM}$ phosphate buffer containing $10 \%$ methanol, Injection time: 15 seconds. The order of peaks; COD-phosphate, CAF, PAR.

\section{Results of Repeatability Studies}

The synthetic mixture was prepared as described in section 2.3 for repeatability studies. The measurement results were obtained 7 times from the prepared synthetic mixture solution. Mean, SD and RSD values were determined for peak area, peak height and migration time values. The results are given in Table 1 . As can be seen from the table, the RSD values for all measurements except of the peak height of PAR $(\mathrm{RSD}=3.44)$ are smaller than 2.6. These results showed the repeatability of the method. 
Table 1

Results of repeatability studies

\begin{tabular}{cc|c|c|c|c|c|c|c|c} 
& \multicolumn{3}{c|}{ PAR } & \multicolumn{3}{c|}{ CAF } & \multicolumn{3}{c}{ COD-phosphate } \\
\cline { 2 - 10 } & Peak Area & Peak Height & $\begin{array}{c}\text { Migration } \\
\text { Time (min) }\end{array}$ & Peak Area & $\begin{array}{c}\text { Peak } \\
\text { Height }\end{array}$ & $\begin{array}{c}\text { Migration } \\
\text { Time (min) }\end{array}$ & $\begin{array}{c}\text { Peak } \\
\text { Area }\end{array}$ & $\begin{array}{c}\text { Peak } \\
\text { Height }\end{array}$ & $\begin{array}{c}\text { Migration Time } \\
(\text { min) }\end{array}$ \\
\hline & 2526.54 & 362.48 & 4.42 & 119.53 & 47.38 & 3.98 & 39.33 & 20.45 & 3.30 \\
& 2531.11 & 351.04 & 4.41 & 120.75 & 47.73 & 3.94 & 39.96 & 20.34 & 3.28 \\
& 2518.95 & 347.04 & 4.43 & 119.67 & 47.43 & 3.95 & 39.50 & 20.16 & 3.27 \\
& 2577.76 & 364.55 & 4.37 & 126.00 & 47.51 & 3.94 & 40.34 & 20.17 & 3.243 \\
& 2575.78 & 376.59 & 4.36 & 123.50 & 47.56 & 3.95 & 40.62 & 20.14 & 3.23 \\
& 2569.53 & 375.66 & 4.36 & 123.55 & 47.42 & 3.94 & 41.46 & 20.50 & 3.22 \\
Mean & 2559.93 & 378.20 & 4.34 & 124.54 & 47.38 & 3.94 & 40.40 & 20.182 & 3.21 \\
SD & 2551.37 & 365.08 & 4.38 & 122.51 & 47.49 & 3.95 & 40.23 & 20.28 & 3.25 \\
RSD & 25.077 & 12.557 & 0.035 & 2.531 & 0.125 & 0.015 & 0.722 & 0.151 & 0.032 \\
\hline
\end{tabular}

Table 2

Results of PAR, CAF and COD-phosphate determination in tablets

\begin{tabular}{|c|c|c|c|c|c|c|}
\hline & \multicolumn{2}{|r|}{ PAR } & \multicolumn{2}{|r|}{ CAF } & \multicolumn{2}{|c|}{ COD- phosphate } \\
\hline $\begin{array}{c}\text { Tablet } \\
\text { No. }\end{array}$ & $\begin{array}{c}\text { Amount } \\
\text { found } \\
\text { (mg/tablet) }\end{array}$ & $\begin{array}{l}\text { Labeled amount } \\
(500 \mathrm{mg} / \text { tablet })\end{array}$ & $\begin{array}{c}\text { Amount } \\
\text { found } \\
\text { (mg/tablet) }\end{array}$ & $\begin{array}{l}\text { Labeled amount } \\
(30 \mathrm{mg} / \text { tablet })\end{array}$ & $\begin{array}{c}\text { Amount } \\
\text { found } \\
\text { (mg/tablet) }\end{array}$ & $\begin{array}{c}\text { Labeled amount } \\
(10 \mathrm{mg} / \text { tablet })\end{array}$ \\
\hline 1 & 500.14 & \multirow{5}{*}{\begin{tabular}{|c|}
$\bar{X}=500.35$ \\
$\mathrm{SD}=1.00$ \\
$\% \mathrm{RSD}=0.20$ \\
$\mathrm{t} . \mathrm{SD} / \sqrt{n}=1.25$ \\
Confidence Interval $=499.10$ \\
-501.60 \\
$\mathrm{p}=0.05$
\end{tabular}} & 29.51 & \multirow{5}{*}{$\begin{array}{c}\bar{X}=29.43 \\
\mathrm{SD}=0.55 \\
\% \mathrm{RSD}=1.88 \\
\text { t.SD } / \sqrt{n}=0.68 \\
\text { Confidence Interval }= \\
28.75-30.11 \\
\mathrm{p}=0.05\end{array}$} & 9.84 & \multirow{5}{*}{$\begin{array}{c}\bar{X}=9.92 \\
\mathrm{SD}=0.09 \\
\% \mathrm{RSD}=0.90 \\
\text { t.SD } / \sqrt{n}=0.11 \\
\text { onfidence Interval }= \\
9.81-10.03 \\
\mathrm{p}=0.05\end{array}$} \\
\hline 2 & 500.34 & & 29.12 & & 9.99 & \\
\hline 3 & 499.42 & & 29.01 & & 10.02 & \\
\hline 4 & 502.03 & & 29.14 & & 9.82 & \\
\hline 5 & 499.81 & & 30.36 & & 9.90 & \\
\hline
\end{tabular}

${ }^{*} \bar{X}$ : Mean, SD: Standard Deviation, RSD: Relative Standard Deviation, $\mathrm{n}$ : Number of experiment, $\mathrm{t}$ : Table $\mathrm{t}$ value from Student $t$ test

Table 3

The accuracy results of PAR, CAF and COD-phosphate in dosage form

\begin{tabular}{|c|c|c|c|c|c|c|c|c|c|c|c|c|}
\hline & \multicolumn{4}{|c|}{ PAR } & \multicolumn{4}{|c|}{ CAF } & \multicolumn{4}{|c|}{ COD- phosphate } \\
\hline $\begin{array}{c}\text { Tablet } \\
\text { No. }\end{array}$ & $\begin{array}{c}\text { Added } \\
(\mu \mathrm{g} / \mathrm{mL})\end{array}$ & $\begin{array}{l}\text { Found } \\
(\mu \mathrm{g} / \mathrm{mL})\end{array}$ & $\begin{array}{c}\text { Recovery } \\
(\%)\end{array}$ & Results & $\begin{array}{c}\text { Added } \\
(\mu \mathrm{g} / \mathrm{mL})\end{array}$ & $\begin{array}{l}\text { Found } \\
(\mu \mathrm{g} / \mathrm{mL})\end{array}$ & $\begin{array}{c}\text { Recovery } \\
(\%)\end{array}$ & Results & $\begin{array}{c}\text { Added } \\
(\mu \mathrm{g} / \mathrm{mL})\end{array}$ & \begin{tabular}{|l|} 
Found \\
$(\mu \mathrm{g} / \mathrm{mL})$
\end{tabular} & $\begin{array}{c}\text { Recovery } \\
(\%)\end{array}$ & Results \\
\hline 1 & 120.17 & 121.33 & 101.0 & $\bar{X}=102.4$ & 7.42 & 7.20 & 97.00 & $\begin{aligned} \bar{X} & =98.0 \\
\mathrm{SD} & =0.84\end{aligned}$ & 2.49 & 2.42 & 97.2 & $\begin{array}{r}\bar{X}=96.9 \\
\mathrm{SD}=1.03\end{array}$ \\
\hline 2 & 125.17 & 129.85 & 103.7 & $\begin{array}{c}\mathrm{SD}=1.39 \\
\% \mathrm{RSD}=1.36 \\
\mathrm{SD} / \sqrt{n}=3\end{array}$ & 7.72 & 7.61 & 98.60 & $\begin{array}{l}\% \mathrm{RSD}=0.86 \\
\mathrm{t} . \mathrm{SD} / \sqrt{n}=2.1\end{array}$ & 2.60 & 2.49 & 95.8 & $\begin{array}{c}\% \mathrm{RSD}=1.07 \\
\mathrm{t} . \mathrm{SD} / \sqrt{n}=\end{array}$ \\
\hline 3 & 130.18 & 133.53 & 102.6 & $\begin{array}{c}\text { Confidence } \\
\text { Interval }=98.9 \\
-105.9 \\
\mathrm{p}=0.05\end{array}$ & 8.03 & 7.90 & 98.40 & $\begin{array}{c}\text { Confidence } \\
\text { Interval }=95.9 \\
-100.1 \\
\mathrm{p}=0.05\end{array}$ & 2.70 & 2.64 & 97.8 & $\begin{array}{c}2.6 \\
\text { Confidence } \\
\text { Interval }=94.3 \\
-99.5 \\
\mathrm{p}=0.05\end{array}$ \\
\hline
\end{tabular}

${ }^{*} \bar{X}$ : Mean, SD: Standard Deviation, RSD: Relative Standard Deviation, n: Number of experiment, t: Table t value from Student $t$ test 


\section{Calibration Results}

The calibration solutions were prepared as described in Section 2.3.1. Three measurements were obtained from each working solution to determine means of peak areas. For each analyte (PAR, CAF and COD-phosphate), the calibration curves were drawn using the mean peak area values versus the concentration $(\mu \mathrm{g} / \mathrm{mL})$. Calibration equation with regression coefficient $\left(r^{2}=0.9995\right)$ was found as $y=0.634 x+0.049$ for COD-phosphate. At the same time calibration equations were found as a $\mathrm{y}=1.2507 \mathrm{x}-0.3702$ $\left(r^{2}=0.9998\right)$ and $y=1.4527 x-35.713 \quad\left(r^{2}=0.9997\right)$ for CAF and PAR respectively. As a result of these studies LOD values were found $0.263 \mu \mathrm{g} / \mathrm{mL}$, $0.533 \mu \mathrm{g} / \mathrm{mL}$ and $0.724 \mu \mathrm{g} / \mathrm{mL}$ for CODphosphate, CAF and PAR respectively. Also LOQ values were found $0.877 \mu \mathrm{g} / \mathrm{mL}, 1.776 \mu \mathrm{g} / \mathrm{mL}$ and $2.415 \mu \mathrm{g} / \mathrm{mL}$ for COD-phosphate, CAF and PAR respectively.

In the calibration study, triple calibration was performed. That is, each dilution contains all three analytes together. Therefore, the effects that can come from the environment to the calibration were minimized. For each analyte, the correlation coefficients of the calibration lines drawn using the peak areas for their concentrations are greater than 0.999. This shows that the relation between the peak area and concentration is linear in the concentration ranges studied. Since the calibration was done in triple mixture, the SD value of the PAR was higher than the other compounds. This led to an increase in LOD and LOQ values for PAR.

\section{Determination of Analytes in Tablets}

The tablet solutions were prepared as described in section 2.3.2. Statistical results for SD, RSD, confidence interval were calculated by obtained the results of 5 tablets (Table 2). The average values obtained in the assays studies are consistent with the values indicated on the tablet. The RSD of the tablet results show the precision of the method.

\section{Recovery Results}

The recovery solutions were prepared as described in Section 2.3.3. Statistical results for $\mathrm{SD}, \mathrm{RSD}$, confidence interval were calculated by obtained the results of measurement (Table 3). Confidence interval values that determine average recovery and $95 \%$ probability of recovery are $102.4 \%$ and $102.4 \pm 3.5 \%$ for PAR, $98 \%$ and $98 \pm$ $2.1 \%$ for CAF, $96.9 \%$ and $96.9 \pm 2.6 \%$ for CODphosphate. The results of the recovery studies for all three analytes are within acceptable values and these results show the accuracy of the method.

\section{CONCLUSION}

There are pharmaceutical preparations in the form of a double and triple mixture comprising PAR, CAF and COD. In these preparations, COD increases the analgesic effect of PAR and has a mild sedative effect, and CAF is used to reduce the sedative effect caused by COD.

In the study, it was aimed to develop a sensitive $\mathrm{CE}$ method that allows simultaneous determination of each active compounds in pharmaceutical tablets containing PAR, CAF and COD-phosphate.

Optimization studies were made by changing the buffer solution, injection time, applied voltage and the molarity of the buffer solution to determine the appropriate working conditions. The validation studies for the repeatability, linearity, precision and accuracy of the developed method have been completed.

It was found that the CE method was accurate and repeatable, the analyte peaks provided sufficient resolution for separation and the analysis time was short $(5$ minutes). LOQ values were found $0.877 \mu \mathrm{g} / \mathrm{mL}, 1.776 \mu \mathrm{g} / \mathrm{mL}$ and $2.415 \mu \mathrm{g} / \mathrm{mL}$ for COD-phosphate, CAF and PAR respectively. So, it said that $C E$ method was sensitive. Because the method can be used to analysis at microgram level. There is no preliminary sample preparation required for separation in this method. Since the use of the device is computer-controlled, both the use of system and the application of the method are simple.

As a result, it was found that the CE method developed was suitable for simultaneous determination of paracetamol, caffeine and codeine phosphate from pharmaceutical dosage forms.

Acknowledgements. The authors would like to thank Gazi University Scientific Research Projects Commission for financial support (Project No: 02/2007-14). We would like to thank Munir Sahin Ilac Sanayi ve Ticaret A.S. for its support to supply active pharmaceutical ingredients. This work was produced from the MSc Dissertation of Koray Cakir (Gazi University, Health Sciences Institute). 


\section{REFERENCES}

1. G. M. Pacifici and K. Allegaert. Curr. Ther. Res. - Clin. Exp., 2015, 77, 24-30.

2. N. B. Simioni, G. G. Oliveira, F. C. Vicentini, M. R. V. Lanza, B. C. Janegitz and O. Fatibello-Filho, Diam. Relat. Mater., 2017, 74, 191-196.

3. D. B. da J. Neves, Food Chem. Toxicol. 2017, 105, 194202.

4. S. Samieirad, B. Shaban, I. Doaltian Shirvan, M. A. Hashemipour, E. Tohidi, H. Afrasiabi and M. Qolizade, J. Cranio-Maxillofacial Surg. 2017, 45, 1614-1621.

5. T. Hyötyläinen, H. Sirén and M. L. Riekkola, J. Chromatogr. A, 1996, 735, 439-447.

6. J. Vilchez, R. Blanc, R. Avidad and A. Navalón, J. Pharm. Biomed. Anal., 1995, 13, 1119-1125.

7. J. T. Franeta, D. Agbaba, S. Eric, S. Pavkov, M. Aleksic and S. Vladimirov, Farmaco., 2002, 57, 709-713.

8. H. I. Ulusoy, E. Y1lmaz and M. Soylak, Microchem. J., 2019, 145, 843-851.

9. J. C. L. Alves and R. J. Poppi, Anal. Chim. Acta., 2009, 642, 212-216.

10. A. Ruiz-Medina, M. L. Fernández-de Córdova, M. J. Ayora-Cañada, M. I. Pascual-Reguera and A. MolinaDíaz, Anal. Chim. Acta., 2000, 404, 131-139.

11. J. Van Staden and M. Tsanwani, Talanta, 2002, 58, 1095-1101.

12. A. A. Ensafi, N. Ahmadi, B. Rezaei and M. M. Abarghoui, Talanta, 2015, 134, 745-753.

13. A. J. Jeevagan and S. A. John, Electrochim. Acta., 2012 77, 137-142.

14. L. Švorc, J. Sochr, J. Svítková, M. Rievaj and D. Bustin, Electrochim. Acta, 2013, 87, 503-510.

15. A. Carolina Torres, M. M. Barsan and C. M. A. Brett, Food Chem., 2014, 149, 215-220.

16. J. Hanaee, Pharm. Acta Helv., 1997, 72, 239-241.

17. A. Criado, S. Cárdenas, M. Gallego and M. Valcárcel, Talanta, 2000, 53, 417-423.

18. L. H. Mazo, B. C. Lourenção, O. Fatibello-Filho, R. C. Rocha-Filho and R. A. Medeiros, Talanta, 2008 78, 748 752.

19. M. Khanmohammadi, M. Soleimani, F. Morovvat, A. B. Garmarudi, M. Khalafbeigi and K. Ghasemi, Thermochim. Acta., 2012, 530, 128-132.
20. E. Deconinck, P. Y. Sacré, S. Baudewyns, P. Courselle and J. De Beer, J. Pharm. Biomed. Anal., 2011, 56, 200-209.

21. M. Tefera, A. Geto, M. Tessema and S. Admassie, Food Chem., 2016, 210, 156-162.

22. J. Sáiz, I. J. Koenka, T. D. Mai, P. C. Hauser and C. GarcíaRuiz, TrAC-Trends Anal. Chem., 2014, 62, 162-172.

23. S. Chittrakarn, P. Penjamras and N. Keawpradub, Forensic Sci. Int., 2012, 217, 81-86.

24. R. Papp, P. Luk, W. M. Mullett and E. Kwong, J. Chromatogr. B, 2007, 858, 282-286.

25. H. Li, C. Zhang, J. Wang, Y. Jiang, J. P. Fawcett and J. Gu, J. Pharm. Biomed. Anal., 2010, 51, 716-722.

26. J. Vojta, P. Hanzlík, A. Jedlička and P. Coufal, J. Pharm. Biomed. Anal., 2015, 102, 85-92.

27. M. J. Ayora Cañada, M. I. Pascual Reguera, A. Ruiz Medina, M. L. Fernández De Córdova and A. Molina Díaz, J. Pharm. Biomed. Anal., 2000, 22, 59-66.

28. J. Liu, B. Ye, K. Zhang, G. Song, Y. Li and K. Li, Sensors Actuators B Chem., 2013, 182, 401-407.

29. A. Wong, A. M. Santos and O. Fatibello-Filho, Sensors Actuators B Chem., 2018, 255, 2264-2273.

30. M. Khairy, B. G. Mahmoud and C. E. Banks, Sensors Actuators B Chem., 2018, 259, 142-154.

31. B. Habibi, M. Abazari and M. H. Pournaghi-Azar, Colloids Surfaces B Biointerfaces, 2014, 114, 89-95.

32. F. Hasanpour, M. Taei, S. Habibollahi, H. Baghlani and H. Salavati, Mater. Sci. Eng. C, 2016, 69, 1-11.

33. A. Ashour, M. A. Hegazy, M. Abdel-Kawy and M. B. ElZeiny, J. Saudi Chem. Soc., 2015, 19, 186-192.

34. C. Xu and B. Li, Spectrochim. Acta - Part A Mol. Biomol. Spectrosc., 2004, 60, 1861-1864.

35. E. Ban, Y. S. Yoo and E. J. Song, Talanta, 2015, 141, $15-20$.

36. A. Mohammadi, M. Shariatpanahi, M. R. Khoshayand, A. Saadatfard and H. Abdollahi, Spectrochim. Acta Part A Mol. Biomol. Spectrosc., 2007, 70, 491-499.

37. M. E. Capella-Peiró, D. Bose, M. F. Rubert and J. Esteve-Romero, J. Chromatogr. B Anal. Technol. Biomed. Life Sci., 2006, 839, 95-101.

38. M. Kartal, J. Pharm. Biomed. Anal., 2001, 26, 857-864.

39. I. Rubashvili, N. Kharukhnishvili and K. Makharadze, Rev. Roum. Chim., 2018, 63, 205-215.

40. E. Kapcak and H. E. Satana Kara, Rev. Roum. Chim., 2018, 63, 1023-1034. 